\title{
Refugees and Immigrants in the Nordic'
}

\section{Anders Buch}

Professor, Aalborg University, Denmark

\section{Sara Kristine Gløjmar Berthou}

Ph.D., Project Manager, The Danish Society of Engineers, Denmark

\section{Thomas Bredgaard}

Professor, Aalborg University, Denmark

mmigration to the Nordic countries has increased significantly in the last 40 years (Pettersen \& Østby 2013:76). Although exact data are hard to come by, it is clear that the term integration, albeit vague and often undefined, has become central in public and political debates. A central premise of most of the debates is the claim that newly arrived immigrants and refugees have not become part of their host societies to a satisfactory extent. Subsequently, an increasing number of initiatives and laws have been introduced in the Nordic countries with the intention to promote integration.

Integration is itself a recent and contested concept. It was not until the early 1990s that it was used in debates on immigrants and refugees (Olwig \& Pærregaard 2007:17). Since then though, the primary usage of the concept refers to the process by which immigrants and refugees adjust to their host countries-a usage that is in fact close to the formal definition of 'assimilation'. When an independent Ministry of Integration was established in Denmark in 2001 for instance, there was little doubt that immigrants and refugees were the objects of its concern (Ibid.)

From the 1990s, a whole administrative apparatus has been established to achieve integration in the Nordic countries. Integration sectors emerged employing project managers, teachers, case workers, and consultants. Policies, laws, and civil society initiatives were launched, and research fields within academia and private research entities set up. The lives of immigrants and refugees became of public concern in the name of integration, the vagueness of the term allowing for and legitimising a broad range of interventions (Ejrnæs 2002:1-2).

This focus on integration emerged 2-3 decades after the large flows of labor migration, in the 1960s, when the Nordic countries recruited guest workers from non-European countries, such as Pakistan and Turkey (Pettersen \& Østby 2013:77). When many of these workers decided to remain, the focus of integration policies was directed at the (foreign) cultural traditions as a contrast to the Nordic way of life. Distinctions were made and explored between different types of migrants and between perceived traditional migrant cultures and modern majority cultures of the host societies. The focus was on the role of migrants as cultural minorities. Later on, during the late 1990s, immigrants were also perceived to be social and political problems that society needed to address (Yvonne Mørck 1998:35).

\footnotetext{
${ }^{1}$ You can find this text and its DOI at https://tidsskrift.dk/njwls/index.
} 
During the last two decades, integration policy and employment policies have become two sides of the same coin (Brochman \& Hagelund 2012; Hagelund \& Kavli 2009; Thomsen 2004). Integration programmes for newly arrived migrants and refugees now consist of employment services such as labor market oriented language education, industry training, and company internships. The co-joining of these two areas has marked a shift in how integration processes are organised. Whereas before the primary marker of difference to be adjusted and integrated were mainly cultural, social, and religious, it now has to do with economic integration and work capability. As a result, employment services is often the first actor to report to after residence permit is obtained.

Several circumstances help explore how integration is now practiced: First, some perceive the growing group of migrants from nonwestern countries as a socioeconomic problem that could harm the Nordic welfare model, due to the increased economic burden (Emerek 2003:4). Second, others perceive migrants as a possible solution to a demographic problem, in which the working population of the host countries is decreasing, which in the long term can lead to a lack of labor force and decreasing competitiveness (Brochman \& Hagelund 2012). Third, dependence on the welfare state potentially leads to social and economic marginalisation, while economic independence strengthens active participation and identification with the majority population (Thomsen 2004:21). Fourth, the deindustrialisation and growth in work functions demanding highly skilled labor also pose challenges for people with no (Western) education. Many have weak links to the labor market and increased poverty are prevalent among immigrants as a result, thus making them the main target of active labor market policies (Brockman $\&$ Hagelund 2012; Järvinen 2004).

An overall sentiment is that immigrants must be integrated into the labor market for the sake of the social and economic cohesion of the welfare state. The arrival of immigrants becomes a challenge in nations where the implicit assumption is that the system works if the majority are economically independent most of the time: 'the unsaid cultural condition for the Danish welfare state is a strong commitment to work and a strong urge to provide for oneself' (Goul Andersen 2006:19). The welfare state is an integral part of the way the Nordic societies are perceived, structured, and practiced: The Nordic countries are welfare states (Jöhncke 2007:50). It has been argued that the distribution of societal goods in the welfare state demand a certain degree of homogeneity, and that community is perhaps even build through this distribution (Olwig og Pærregaard 2007:23). National identity in this sense has more to do with a commitment to the welfare ideology, than it has to do with Christianity or Christmas trees (Jöhncke 2007:59). Immigrants potentially pose a fundamental threat to consensus and social cohesion since the universality of welfare benefits is challenged and may be perceived as something 'for them' paid 'by us'. The economic tools of the welfare state, such as labor market policies, therefore becomes central to national integration.

Regulated labor markets and universalistic welfare models have thus become a characteristic of the Nordic countries. The welfare models have been supported by high employment and participation rates, economic prosperity, collective bargaining, organised working life and equality in income distribution (Dølvik et al. 2015). But it seems fair to say that migration pose both an opportunity and challenge to the Nordic labor market and welfare models. Since the unprecedented inflow of refugees from 2014, the 'refugee crisis' has been high on the Nordic policy agenda. The Nordic countries received a higher proportion of asylum seekers than the rest of the EU (Dustmann et al.

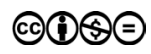


2016). Since 2004, there has also been a sharp increase in the number of labor migrants from the new EU member states.

Labor migrants are filling gaps in labor supply and not only provide human capital in specific sectors of industry but also raise concerns about equality in pay and working conditions, organised working life and integration of unemployed with native backgrounds. Labor migration intensifies competition for the lowest paid jobs and make labor market integration harder for groups with low skills and limited work experience (Nordic Economic Policy Review 2017). Low participation and employment rates of refugees, family reunified foreigners and migrants from third-world countries thus challenge the financial sustainability and social cohesion of the Nordic welfare states. The Nordic countries struggle to find effective ways to integrate nonwestern migrants and refugees (Djuve \& Grødem 2014), and in recent years, policy reforms of the frameworks for labor market integration have been introduced in the Nordic countries.

This issue brings four articles that discuss the challenges of refugees and immigrants in Norway, Sweden and Denmark, and how labor market initiatives and policies address these challenges.

The first article 'Integration of Refugees on the Danish Labor Market' by Thomas Bredgaard and Trine Lund Thomsen reviews the literature in order to identify the main barriers and challenges that obstruct labor market integration of refugees. On a conceptual level, the literature focuses on three different, but related, approaches that seek to identify and overcome the barriers. The supply-side approach focus on the refugees' lack of adequtate skills, qualifications and motivation to integrate on the labor marked. The demand-side approach pays attention to employers discrimination of refugees in recruitment process, and the matching-approach is concerned with the lack of credible information and contacts between refugees and employers. Traditionally, many labor market policies and initiatives have focused on the supply-side approach by initiating language courses and educational programmes to strengthen refugees' competencies. But the efforts of these initiatives have not resulted in significant improvement of the employment rates of refugees. In the second part of the article, Bredgaard and Thomsen discuss a 'paradigm shift' in the policy framework in Denmark that downplays traditonal supply-side approaches in favour of matching approaches: refugees are allocated to work experience programmes in local workpaces in parallel with language training. Although it is to early to evaluate the effects of the policy shift, the authors detect preliminary positive results.

The article 'Perfect Match? The Practice Ecology of a Labor Market Initiative for Refugees’ by Sara Gløjmar Berthou and Anders Buch show how a supposedly perfect match between Danish employers and refugees with a professional engineering background ended up as a failure. The article investigates the 'practice ecology' of a labor market project run by the Danish Society of Engineers (IDA). The idea of the project was to match refugees with an engineering background with Danish technology companies lacking qualified engineers. During the course of 18 months, the Professional Engineering Academy (PEA) in IDA trained, placed and mentored around 50 candidates, but failed to meet the primary objective of the programme, that is to integrate refugees on the ordinary labor market. Searching for plausible explanations, Berthou and Buch look beyond the traditional barriers on the supply-, demand- and matching-side of the labor market and study the 'practice ecology' of the programme, that is the set of interwoven sayings, doings and relatings of the initiative. In practice, the PEA-initiative clashed with 
the media discourse, the new legal framework and the motives of the companies. The media framed the issue in the context of the 'refugee crisis', the legal framework and municipalities emphasised short-term 'work first' approaches, and companies referred to CSR-policies and established internships rather than ordinary employment relationships. This practice ecology in effect worked against the intentions of the PEA-initiative and hampered a sustainable, long-term integration of refugees with an engineering background on the Danish labor market.

In the article 'Making Refugees Work? Individualized Work Strategies in the Swedish Refugee Settlement Program' by Eva Wikström and Petra Ahnlund, we turn to the Swedish context. In a qualitative study of interviews and individual action plans, the authors examine how integration is put into practice in refugee settlements. According to policy shifts, the activation efforts in the settlements are now foucused on labor market integration and individual responsibility, whereas previous policies were concerned with 'support' and social responsibility. This shift aligns with prevailant 'workfare ideologies' and 'empowerment ideologies' that sees the role of labor market programmes as disciplining. In discussing the changes in refugee integration policies, Wikström and Ahnlund point to the potential problematic effects of this intensified focus on employment. The shift seems to put initiatives directed towards refugees on the same footing as initiatives directed towards unemployed in general, and it thus ignores the complex and traumatic background of the refugees.

In relation to concerns about increasing polarisation and segmentation of the labor market, the last article 'Motivation, Migration, and Non-standard Employment: A Survey Among Temporary Agency Workers' by Anders Underthun and Aadne Aasland studies why migrants to a higher extent than native workers end up in nonstandard jobs. Through a survey of temporary agency workers (TAWs) in Norway, they find that motivation is more important than country background for finding nonstandard employment suitable both in the present and in the future. Underthun and Aasland conclude that while acceptance of nonstandard employment among TWA workers in Norway appears to have been strongly associated with country background or the type of industry to which the TWAs provide services, the motivation for engaging in TWA work explains most of the variation in their regression models.

\section{References}

Bevelander, P., R. Bilde, I. Dahlstedt, M. Eskelund, L. M. Hansen, M. Macura, K. G. Pedersen and L. Østby (2013). Scandinavia's Population Groups Originating from Developing Countries: Change and Integration, Current Themes in IMER Research no. 14, Malmø University.

Brochmann, G. and A. Hagelund (2012). Immigration Policy and the Welfare State 1945-2010, Basingstoke: Palgrave Macmillan.

Djuve, A. B. and A. S. Grødem, eds. (2014). Innvandring og arbeidsmarkedsintegrering i Norden [Immigration and labor market arrangements in the Nordic], NordMod 2030, delrapport 11, FAFO report. https:/www.fafo.no/images/pub/2014/20374.pdf.

Ejrnæs, M. (2002). Etniske minoriteters tilpasning til livet i Danmark - forholdet mellem etniske minoriteter og majoritetssamfundet [Accomodation of ethnic minorities to everyday life in Denmark - the relationship between ethnic minorities and the majority society], AMID Working Paper Series 18/2002. 
Emerek, Ruth, Aalborg Universitet (2003). Integration - eller inklusion? Den danske diskussion om integration [Integration - or exclusion? The Danish discussion about integration]. AMID Working Paper Series 31/2003.

Goul Andersen, J. (2006). Immigration and the Legitimacy of the Scandinavian Welfare State. Some Preliminary Danish Findings, Amid Working Paper Series 53, Aalborg University.

Hagelund, A. and Kavli, H. (2009). If work is out of sight. Activation and citizenship for new refugees, Journal of European Social Policy.

Hedetoft, U. R., Emerek, R., Poulsen, J. and Larsen, J. (2002). Integrationsforskningen i Danmark 1980-2002. Indvandrere og Integration [Research on integration in Denmark 1980-2002. Immigrants and Integration], København: Ministeriet for Flygninge.

Jöhncke, S. (2007). Velfærdsstaten som integrationsprojekt. Integration. Antropologiske Perspektiver [The welfare state as integration project. Integration. Anthropological perspectives]. Museum Tusculanums Forlag

Järvinen, M. (2004). Hjemløse flygtninge og indvandrere [Homeless refugees and immigrants], København: Hans Reitzels Forlag.

Mørck, Y. (1998). Bindestregsdanskere. Fortællinger om køn, generationer og etnicitet [Hyphen Danes. Stories about gender, generations, and ethnicity], Frederiksberg: Forlaget Sociologi.

Nordic Economic Policy Review (2017). Labor Market Integration in the Nordic Countries, Nordic Council of Ministers, http://www.diva-portal.org/smash/record.jsf?pid=diva2\%3A1090694\&dswid $=-4697$.

Olwig, K. F. and Pærregaard, K. (2007). Integration. Antropologiske perspektiver [Integration. Anthropological perspectives], Museum Tusculanums Forlag.

Pettersen, S. V. and Østby, S. (2013). Skandinavisk komparativ statistikk om integrering. Innvandrere i Norge, Sverige og Danmark [Scandinavian comparative statistics on integration. Immigration in Norway, Sweden, and Denmark], Samfunnsspeilet 5/2013. Statistisk sentralbyrå.

Thomsen, M. H. (2004). Med kurs mod mangfoldighed? - Begreber og praksis i integrationsindsatsen [Heading towards diversity? Concepts and practise in integration enterprise], Hans Reitzels Forlag. 